\title{
First report of Zeatylenchus pittosporum on Pittosporum crassifolium
}

\author{
Dongmei $\mathrm{Li}^{1} \cdot$ Yu Mei $\mathrm{Xu}^{2,3} \cdot$ Zeng Qi Zhao ${ }^{3}$
}

Received: 2 November 2016 / Accepted: 9 February 2017 / Published online: 18 February 2017

(C) Australasian Plant Pathology Society Inc. 2017

\begin{abstract}
Zeatylenchus pittosporum is reported for the first time from Pittosporum crassifolium at Auckland, New Zealand. Nematodes were isolated from the leaves with brown or yellow chlorotic spots and identified as Z. pittosporum based on morphology, SSU and LSU of rDNA sequences analysis.
\end{abstract}

Keywords Pittosporum crassifolium - Zeatylenchus pittosporum $\cdot$ New host $\cdot$ Nematode $\cdot$ Molecular $\cdot$ SSU $\cdot$ LSU . Morphology

Zeatylenchus pittosporum (Tylenchida: Anguinidae) causes brown or yellow chlorotic spots was first recorded in Pittosporum tenuifolium from Hahei, on the North Island of New Zealand in 2012 (Zhao et al. 2013). This was the first report of anguinids as parasites in the Pittosporaceae plants (Zhao et al. 2013). The anguinid host range includes both grasses and broad-leaved plants, and many gall formers are known to be host-specific. The family Anguinidae includes nematodes that are fungal feeders and parasites of the aerial parts of plants (Siddiqi 2000). Most genera and species of Anguinidae induce galls on aerial parts of plants (Siddiqi 2000).

Zeng Qi Zhao

zhaoz@landcareresearch.co.nz

1 Plant Health and Environment Laboratory, Ministry for Primary Industries, PO Box 2095, Auckland 1140, New Zealand

2 Laboratory of Nematology, Department of Plant Pathology, Agronomy College, Shanxi Agricultural University, Taigu 030801, China

3 Landcare Research, Private Bag 92170, Auckland Mail Centre, Auckland 1142, New Zealand
In June 2013, leaves of $P$. crassifolium with brown or yellow spots symptom were also observed and collected from the Auckland airport and sent to the Plant Health and Environment Laboratory, Ministry for Primary Industries (MPI) for identification. Nematodes were isolated from the leaves and identified as Z. pittosporum. Subsequently, permanent nematode slides with collection number 28185 and 30037 were received from the AureQuality, New Zealand. All the specimens on the slides were isolated from the leaves of $P$. crassifolium, collected from Bay of Islands in May 2006 and from Auckland in July 2007, respectively. The nematodes from both locations were identified as $Z$. pittosporum. In fact Z. pittosporum from Bay of Islands, collected by AureQuality, was the earliest records for Z. pittosporum from Pittosporum trees in New Zealand.

Zeatylenchus pittosporum causes brown or yellow chlorotic spots on both P. tenuifolium leaves (Zhao et al. 2013) and P. crassifolium (Fig. 1). Symptoms of infestation were nonspecific, brown or yellow chlorotic spots and discoloured areas expanded along the vines on leaves (Fig. 1). The symptoms were patchy on the trees surveyed. No cavities, swellings or abnormal growths and no development of nutritive tissue were observed in the leaves. Although leaf spots on Pittosporum caused by fungi have been reported (Chase and Simone 2001), fungal hyphae were not observed in the Pittosporum leaves. The infested $P$. crassifolium leaves were examined under the dissecting microscope. All life stages of $Z$. pittosporum were found in the mesophyll, indicating that the life cycle is completed within the leaves, and the robust form of the stylet of the nematode is consistent with it being a plant feeder (Fig. 2). Therefore, the results indicated that the brown or yellow spots and discolouration of the leaves were caused by the nematodes, Z. pittosporum.

In general, the isolates of $Z$. pittosporum from $P$. crassifolium correspond well to the descriptions of 


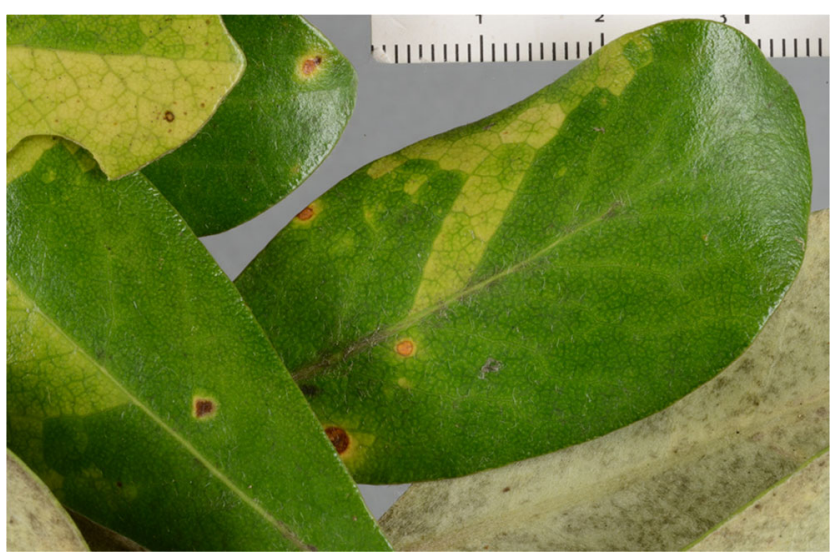

Fig. 1 Photograph of symptoms of yellow chlorotic spot on leaves of Pittosporum crassifolium caused by Zeatylenchus pittosporum

Zeatylenchus pittosporum given by Zhao et al. (2013) (Table 1). Z. pittosporum is morphologically characterised by having slender males and females with head offset and distinctly narrower than body diam (Fig. 2a and b). In some specimens, a small stylet, pharynx with a small non-muscular median bulb and glands in two parts with ventral and subventral glands overlapping the intestine, secretory/ excretory pore opening at level of the retracted stylet knobs (Fig. 2b), anterior to the median bulb, females with a quadricolumella and post-uterine sac, males with arcuate spicules and an adanal bursa that extends to $30 \%$ of distance to the tail tip, and a conoid tail that is dorsally off-set with a spicate tip (Fig. 2d). It has both males and females free-living in leaves of $P$. crassifolium and its feeding does not induce galls (Fig. 1). Permanent slides of the $Z$. pittosporum specimens were stored in the nematode collection of AureQuality, New Zealand, with the collection numbers of 28185 and 30037.

To confirm the morphological identification, the individual nematode was used for DNA extraction. Individual live nematodes were lysed in a buffer of $20 \mu$ l containing proteinase K (Williams et al. 1992) and DNA was extracted using the method of Zheng et al. (2002). Extracted DNA was used for PCR amplification of the nearly full length of small subunit (SSU) rDNA gene with primers, $1096 \mathrm{~F}$ and $1912 \mathrm{R}$ for the first fragment and $1813 \mathrm{~F}$ and 2646R for the second fragment (Holterman et al. 2006). Primers, D2A and D3B (Nunn 1992) were used to amplify the D2/D3 expansion segments of the large subunit (LSU) rDNA gene. The PCR compositions and cycling conditions for the amplification of the LSU and SSU genes, and sequencing were conducted as per Zhao et al. (2013). BLAST search analysis showed that the obtained DNA sequences of the LSU and SSU shared 99-100\% maximal identity with those of the GenBank-derived Z. pittosporum isolates (JQ586255 SSU, JQ586256 LSU). Identical sequence for the SSU gene while 5 SNPs out of $729 \mathrm{bp}$ were observed in the $\mathrm{D} 2 / \mathrm{D} 3$ region of the LSU sequences for $Z$. pittosporum
Fig. 2 Light microscope photographs of Zeatylenchus pittosporum isolated from infected leaf of Pittosporum crassifolium. a: male anterior part and stylet; $\mathbf{b}$ : female anterior part, stylet and excretory pore; $\mathbf{c}$ : male lateral lines; $\mathbf{d}$ : male spicules and spicate tail tip. e: female tail and spike tail tip. f: female vulva (Scale bars: all $=10 \mu \mathrm{m}$ )

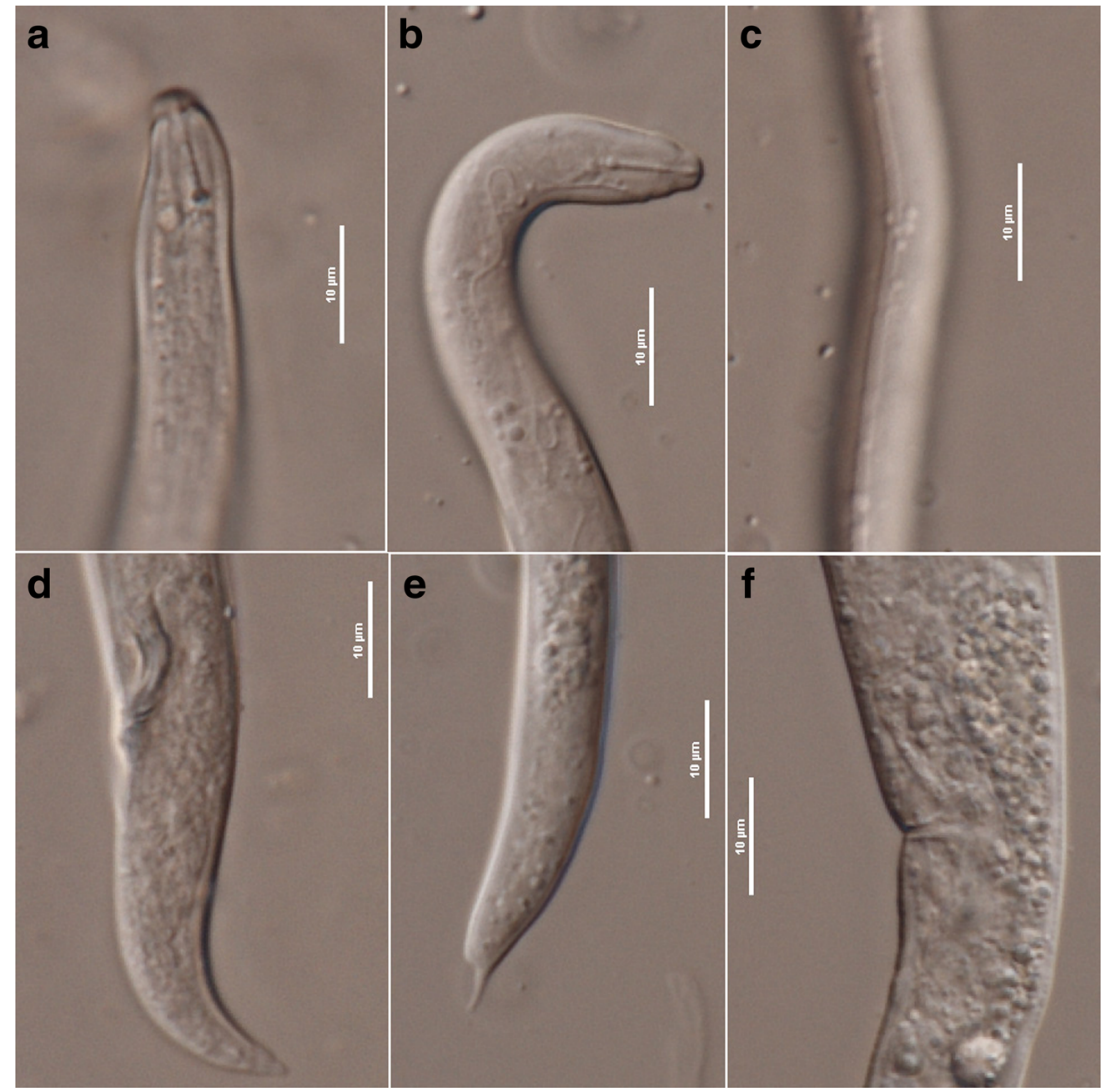


Table 1 Comparative morphometrics of Zeatylenchus pittosporum from Pittosporum crassifolium and P. tenuifolium. All measurements given as mean $(\mu \mathrm{m}) \pm$ s.d. (range)

\begin{tabular}{|c|c|c|c|c|c|c|}
\hline \multirow[t]{2}{*}{ Character } & \multicolumn{4}{|l|}{ Female } & \multicolumn{2}{|l|}{ Male } \\
\hline & $\begin{array}{l}\text { P. crassifolium } \\
\text { (this study) }\end{array}$ & $\begin{array}{l}\text { P. tenuifolium } \\
\text { (Zhao et al. 2013) }\end{array}$ & $\begin{array}{l}\text { P. crassifolium } \\
\text { (this study) }\end{array}$ & $\begin{array}{l}\text { P. tenuifolium } \\
\text { (Zhao et al. 2013) }\end{array}$ & $\begin{array}{l}\text { P. crassifolium } \\
\text { (this study) }\end{array}$ & $\begin{array}{l}\text { P. tenuifolium } \\
\text { (Zhao et al. 2013) }\end{array}$ \\
\hline$n$ & 13 (slender) & 10 (slender) & 2 (obese) & 16 (obese) & 4 & 15 \\
\hline $\mathrm{L}$ & $462 \pm 50(352-558)$ & $533 \pm 31(450-561)$ & $592 \pm 14(583-602)$ & $579 \pm 23(543-623)$ & $514 \pm 94(391-618)$ & $553 \pm 35(509-659)$ \\
\hline $\mathrm{a}$ & $53.1 \pm 7.0(36.8-63.7)$ & $59.2 \pm 4.9(47.2-64.7)$ & $36.0 \pm 1.8(34.7-37.3)$ & $39.3 \pm 3.2(34.7-44.1)$ & $43.5 \pm 5.4(35.9-48.5)$ & $54.7 \pm 5.9(46.7-70.0)$ \\
\hline $\mathrm{c}$ & $20.3 \pm 1.9(17.2-22.7)$ & $20.3 \pm 1.1(19.7-23.3)$ & $23.5 \pm 2.2(21.9-25.0)$ & $21.2 \pm 1.7(18.8-25.0)$ & $16.8 \pm 0.9(16.3-17.9)$ & $19.1 \pm 1.5(15.5-21.2)$ \\
\hline$c^{\prime}$ & $3.2 \pm 0.4(2.5-3.9)$ & $3.5 \pm 0.2(3.1-3.7)$ & $2.9 \pm 0.3(2.7-3.1)$ & $3.4 \pm 0.3(2.7-3.9)$ & $3.0 \pm 0.5(2.4-3.3)$ & $3.6 \pm 0.4(3.0-4.3)$ \\
\hline $\mathrm{V} / \mathrm{T}$ & $77.1 \pm 1.2(74.3-78.4)$ & $77.1 \pm 1.0(76.0-78.9)$ & $79.4 \pm 0.6(78.9-79.4)$ & $78.3 \pm 1.0(75.5-79.9)$ & - & $94.9 \pm 0.4(93.8-95.5)$ \\
\hline Max. body diam. & $8.8 \pm 0.8(7.7-9.7)$ & $9.0 \pm 0.4(8.5-9.6)$ & $16.5 \pm 0.5(16.1-16.8)$ & $14.8 \pm 1.3(12.3-16.8)$ & $11.7 \pm 0.8(10.9-12.8)$ & $10.2 \pm 0.7(9.0-11.5)$ \\
\hline Stylet length & $7.3 \pm 0.3(6.9-8.0)$ & $9.5 \pm 0.9(7.3-10.1)$ & $10.4 \pm 0.4(10.1-10.7)$ & $10.3 \pm 0.4(9.3-10.8)$ & $8.3 \pm 0.9(7.0-9.2)$ & $10.3 \pm 0.3(9.7-10.8)$ \\
\hline $\begin{array}{l}\text { Excretory pore from } \\
\text { anterior end }\end{array}$ & $5.9 \pm 0.4(5.6-6.2)$ & $7.2 \pm 0.7(6.4-8.3)$ & $8.5 \pm 0.7(8.0-9.0)$ & $8.2 \pm 05(7.3-9.5)$ & & $7.9 \pm 0.8(7.2-9.4)$ \\
\hline Spicule length & & - & - & - & $9.9 \pm 1.5(8.6-11.6)$ & $11.8 \pm 1.6(9.2-14.3)$ \\
\hline Post-uterine sac length & $10.5 \pm 1.2(9.4-12.2)$ & $12.5 \pm 1.9(8.4-15.8)$ & $20.4 \pm 0.8(19.9-21.0)$ & $20.1 \pm 3.2(15.7-26.4)$ & & - \\
\hline Tail length & $23.0 \pm 2.2(18.7-26.1)$ & $26.7 \pm 1.6(22.7-28.0)$ & $25.3 \pm 1.8(24.0-26.6)$ & $27.4 \pm 1.7(24.1-29.8)$ & $29.5 \pm 5.5(23.9-34.6)$ & $29.1 \pm 2.6(25.3-35.8)$ \\
\hline Anal/cloacal body diam. & $7.2 \pm 0.6(6.5-8.2)$ & $7.7 \pm 0.2(7.3-8.1)$ & $8.8 \pm 0.3(8.6-9.0)$ & $8.2 \pm 0.5(7.3-8.6)$ & $10.0 \pm 0.6(9.4-10.5)$ & $8.0 \pm 0.7(6.9-9.2)$ \\
\hline
\end{tabular}

from $P$. crassifolium and $P$. tenuifolium, indicating there is slightly variation among $Z$. pittosporum species from different hosts. The sequences were submitted to GenBank under the accession numbers KY067422 for SSU and KY067423 for LSU.
To further resolve the phylogenetic relationship, the D2/D3 region of the $28 \mathrm{~S}$ rRNA sequences derived from $P$. crassifolium was used to construct phylogenetic tree. The related LSU sequences were aligned in ClustalX2 (Larkin et al. 2007) with the default parameter values. ModelTest 3.04 (Posada and Crandall
Fig. 3 Bayesian phylogenetic tree inferred from LSU gene DNA sequences. Posterior probabilities greater than $50 \%$ are given on appropriate clades. Nematode species and GenBank Accession numbers are listed for each taxon

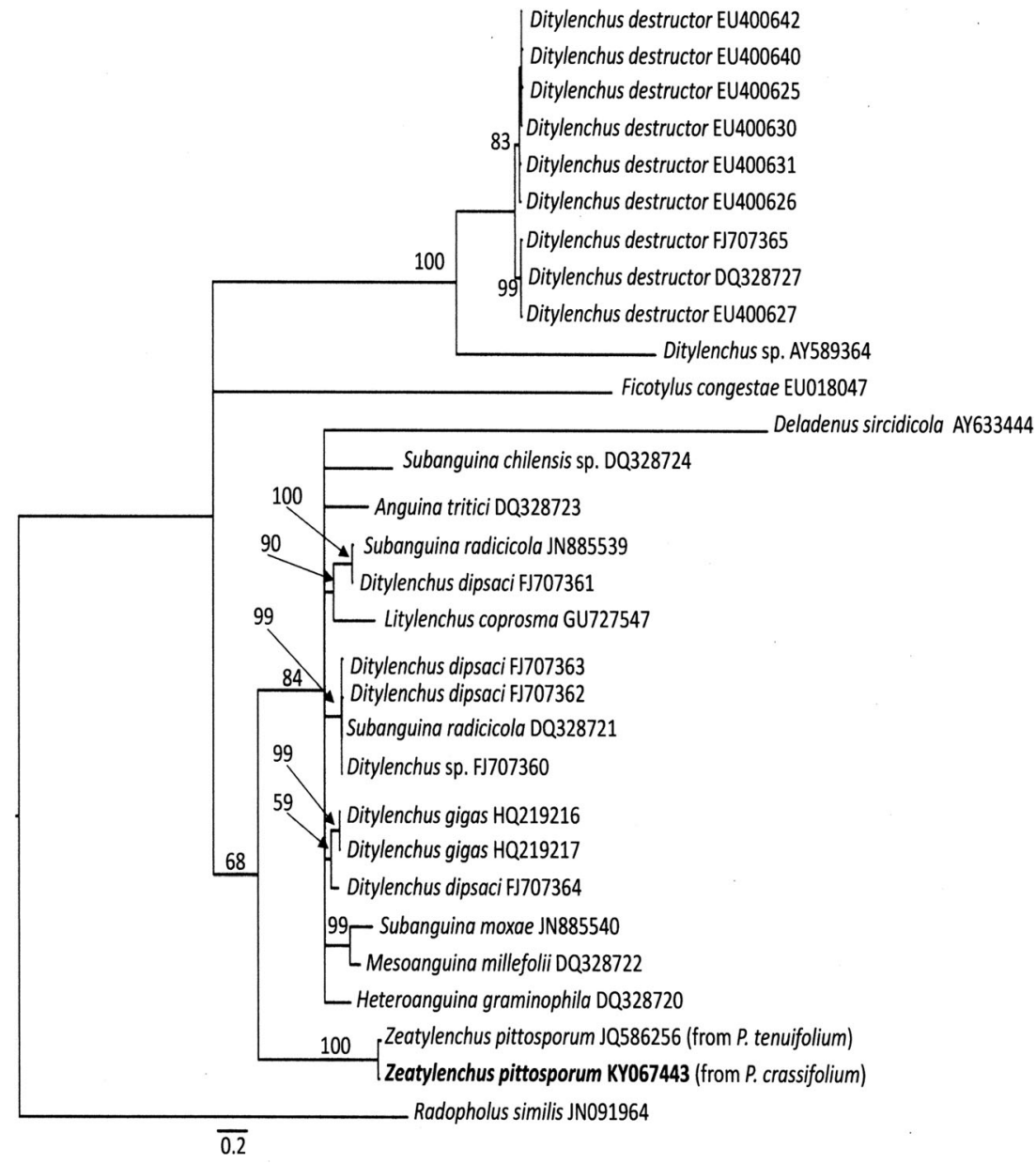


1998) and PAUP*4.0b10 (Swofford 2002) were used to select the best AIC model. A Bayesian tree was constructed with MrBayes 3.1.2 (Ronquist and Huelsenbeck 2003) and rooted using Radopholus similis (Cobb 1893) Thorne, 1949 as outgroup. The phylogenetic tree showed that $Z$. pittosporum derived from $P$. crassifolium formed a clade with $Z$. pittosporum of $P$. tenuifolium with $100 \mathrm{pp}$ values support, and well distant from the other genera (Fig. 3).

Although root-knot nematodes, Meloidogyne and spiral nematodes, Helicotylenchus, have been detected in the rhizosphere of Pittosporum trees (Knight et al. 1997), no $Z$. pittosporum were found in soil collected from under infested P. crassifolium and P. tenuifolium trees. Pittosporum Banks ex Sol. contains about 200 species across Asia, Australia, New Zealand, the Pacific Islands and South Africa (Poole and Lane 1990). P. crassifolium and P. tenuifolium are both native to New Zealand and widely grown as ornamental plants in subtropical areas. This nematode is probably endemic to New Zealand as it was collected from P. tenuifolium and P. crassifolium endemic New Zealand plants.

In conclusion, this is the first report of new host P. crassifolium for Z pittosporum. The brown or yellow spots, caused by $Z$. pittosporum were observed only in the leaves of two Pittosporum species, $P$. crassifolium and P. tenuifolium. No other hosts have been reported so far. Whether Z. pittosporum occurs in other species of Pittosporum species needs to be further surveyed.

\footnotetext{
Acknowledgements We thank Mr Graeme Page, AsureQuality, New Zealand for providing the permanent specimens of $Z$. pittosporum. This research was supported by core funding for Crown Research Institutes from the Ministry of Business, Innovation and Employment's Science and Innovation Group.
}

\section{References}

Chase AR, Simone GW (2001) Diseases of Pittosporum in Florida. Plant Pathogen Fact Sheet. http://plantpath.ifas.ufl.edu/media/ plantpathifasufledu/factsheets/pp0029.pdf

Holterman M, Van Der Wurff A, van den Elsen S, van Megen H, Bongers T, Holovacgov O, Bakker J, Helder J (2006) Phylum-wide analysis of SSU rDNA reveals deep phylogenetic relationships among nematodes and accelerated evolution toward crown clades. Mol Biol Evol 13:1792-1800

Knight KW, Barber CJ, Page GD (1997) Plant-parasitic nematodes of New Zealand recorded by Host Association. Suppl J Nematol 29: 640-656

Larkin MA, Blackshields G, Brown NP, Chenna R, McGettigan PA, McWilliam H, Valentin F, Wallace IM, Wilm A, Lopez R, Thompson JD, Gibson TJ, Higgins DG (2007) Clustal W and Clustal X version 2.0. Bioinformatics 23:2947-2948

Nunn GB (1992) Nematode molecular evolution. Ph.D. Thesis, University of Nottingham, Nottingham, UK

Poole L, Lane N (1990) Trees and shrubs of New Zealand. DSIR Publishing, Wellington

Posada D, Crandall KA (1998) Modeltest: testing the model of DNA substitution. Bioinformatics 14:817-818

Ronquist F, Huelsenbeck JP (2003) MR BAYES: Bayesian inference of phylogenetic trees. Bioinformatics 19:1572-1574

Siddiqi MR (2000) Tylenchida parasites of plants and insects, 2nd edn. CABI Publishing, Wallingford, 833

Swofford DL (2002) PAUP*. Phylogenetic Analysis Using Parsimony (and Other Methods), Version 4. Sinauer Associates, Sunderland

Williams BD, Schrank B, Huynh C, Shownkeen R, Waterston RH (1992) A genetic mapping system in Caenorhabditis elegans based on polymorphic sequence-tagged sites. Genetics 131:609-624

Zhao ZQ, Davies K, Alexander B, Riley IT (2013) Zeatylenchus pittosporum gen. n., sp. n. (Tylenchida: Anguinata), from leaves of Pittosporum tenuifolium (Pittosporaceae) in New Zealand. Nematology 15:172-212

Zheng JW, Subbotin SA, He SS, Gu JF, Moens M (2002) Molecular characterisation of some Asian isolates of Bursaphelenchus xylophilus and B. mucronatus using PCR-RFLPs and sequences of ribosomal DNA. Russ J Nematol 11:17-22 